\title{
Pemanfaatan Plastik Polipropilen Standing Pouch Sebagai Salah Satu Kemasan Sterilisasi Peralatan Laboratorium
}

\author{
Istini $^{1}$ \\ ${ }^{1}$ Laboratorium Penelitian dan Pengujian Terpadu Universitas Gadjah Mada Yogyakarta \\ Email: Istini@ugm.ac.id
}

Submisi: 26 Agustus 2019; Penerimaan: 30 Juli 2020

\begin{abstract}
ABSTRAK
Salah satu penelitian yang dilakukan di laboratorium adalah kultur sel. Penelitian tersebut membutuhkan lingkungan yang steril, meliputi alat, ruang, peralatan pendukung, serta personil laboratorium. Sterilisasi sangat berperan penting bagi kelancaran hasil kultur sel. Peralatan pendukung yang steril juga berperan penting dalam upaya pencegahan agar penelitian terhindar dari kontaminasi. Peralatan pendukung ini antara lain terdiri dari: tip kuning, tip biru, tabung 1,5 ml, petri dish, alat bedah, dan tabung $15 \mathrm{ml}$. Peralatan tersebut perlu dikemas sebelum dilakukan sterilisasi dengan autoklaf. Bahan atau wadah untuk mengemas peralatan pendukung diperlukan untuk menjaga peralatan dari tekanan dan suhu tinggi selama proses sterilisasi dengan autoclave. Salah satu bahan alternative yang dapat digunakan untuk mengemas adalah plastik prolipropilen standing pouch. Percobaan ini bertujuan untuk mengetahui apakah plastik standing pouch dapat dipakai sebagai salah satu kemasan sterilisasi peralatan laboratorium sehingga dapat menunjang kegiatan penelitian di laboratorium. Percobaan dilakukan dengan memasukkan peralatan laboratorium diantaranya tip biru, tip kuning, tabung 1,5 ml, dan petridish, ke dalam empat macam bahan pengemas yaitu plastik polipropilen standing pouch, kertas payung, plastik polipropilen tebal, dan kotak tip pabrikan kemudian disterilisasi menggunakan autoklaf selama 15 menit. Percobaan selanjutnya adalah pengecekan sterilitas, yaitu tip biru yang sudah steril dimasukkan ke dalam botol steril berisi medium RPMI dan sebagai kontrol adalah botol steril yang berisi medium $R P M I$ saja. Botol dimasukkan ke dalam inkubator $\mathrm{CO}_{2}$ dengan suhu $37^{\circ} \mathrm{C}$ kemudian dilakukan pengamatan selama tiga hari. Setelah tiga hari botol blanko dan botol perlakuan tetap jernih, hal ini menandakan tidak terjadi kontaminasi. Percobaan ini membuktikan bahwa plastik polipropilen standing pouch dapat digunakan sebagai salah satu bahan pengemas peralatan untuk sterilisasi di laboratorium yang praktis.
\end{abstract}

Kata kunci : plastik polipropilen; standing pouch; sterilisasi; bahan pengemas.

\section{PENDAHULUAN}

Proses penelitian di laboratorium yang dilakukan oleh mahasiswa atau peneliti sebagian besar menggunakan peralatan yang steril. Penelitian yang memerlukan peralatan steril antara lain: kultur bakteri, kultur sel, kultur tanaman dan penelitian di bidang biologi molekuler seperti DNA/RNA. Peralatan yang perlu disterilkan antara lain: tabung kaca,alat bedah, tabung plastik berbagai ukuran, petridish, tip kuning, dan tip biru. Peneliti memerlukan bahan untuk mengemas dan melindungi peralatan tersebut selama proses sterilisasi dengan tekanan dan suhu tinggi di dalam alat autoklaf. Bahan pengemas yang sering dipakai antara lain: kertas payung, kertas koran, rak tip, aluminium foil, dan plastik tebal, akan tetapi bahan-bahan tersebut masih memiliki kelemahan. Penggunaan kertas payung/koran sering meninggalkan bercak pada peralatan setelah 
disterilisasi di dalam autoklaf. Penggunaan plastik tebal masih membutuhkan staples dan selotip yang terkadang kurang rapat. Penggunaan alumunium foil mudah robek sedangkan rak tip harganya relatif mahal.

Saat ini banyak terdapat produk plastik yang beredar dipasaran antara lain: plastik polipropilen standing pouch. Plastik ini biasa digunakan untuk mengemas makanan, karena memiliki kelebihan yaitu murah, mudah didapatkan di toko plastik, tebal, transparan, dan terdapat klip pengunci. Untuk itu dilakukan percobaan terhadap plastik polypropilen standing pouch sebagai bahan pengemas sterilisasi peralatan laboratorium dengan autoklaf yang bersuhu tinggi. Sterilisasi adalah proses untuk menghilangkan semua jenis miroorganisme yang hidup dalam suatu benda yaitu protozoa, fungi, bakteri, mycoplasma, dan virus. Sterilisasi berfungsi menjaga kebersihan atau sterilitas suatu benda yang akan dipergunakan. Beberapa peneltian dilaboratorium misalnya penelitian kultur dan biologi molekuler sangat membutuhkan kondisi dan peralatan yang steril.

\section{TINJAUAN PUSTAKA}

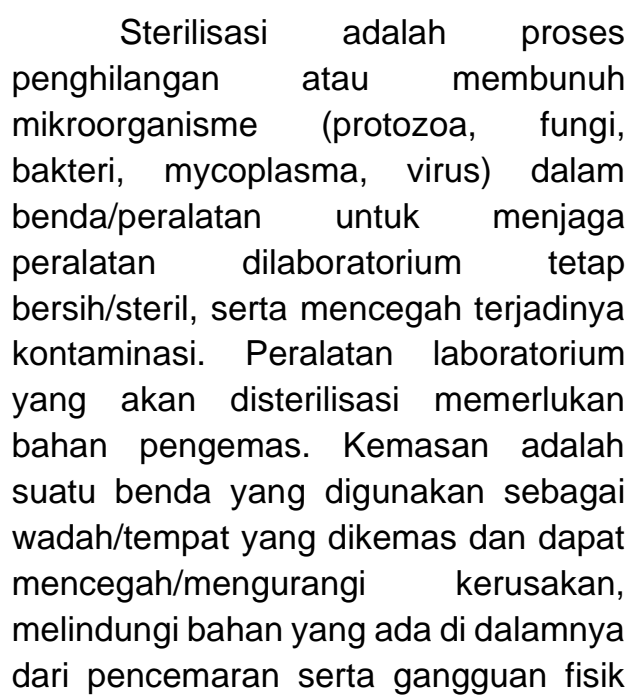

seperti gesekan, benturan dan getaran (Nurminah, 2002).

Plastik merupakan bahan pengemas yang saat ini berkembang pesat. Plastik digunakan untuk mengemas berbagai macam jenis makanan dan minuman. Penggunaan plastik sebagai bahan pengemas mempunyai keunggulan dibanding bahan pengemas lain karena bersifat ringan, transparan, kuat, murah, mudah didapat ditoko plastik. Plastik juga memiliki kelemahan yaitu, beberapa jenis tidak tahan panas, dan plastik termasuk bahan yang tidak dapat dihancurkan dengan cepat dan alami (nonbiodegradable) (Latief, 2000).

Plastik polipropilen adalah salah satu jenis plastik yang banyak digunakan dalam pembuatan botol minuman, kotak makanan, dan sebagai tempat penyimpanan makanan karena termasuk jenis plastik terbaik. Bahan plastik ini mampu mencegah terjadinya reaksi kimia dan mempunyai sifat tahan panas. Jenis plastik polipropilen (PP) memiliki sifat lebih kaku, kuat dan ringan daripada polietilen dengan daya tembus uap air yang rendah, memiliki ketahanan yang baik terhadap lemak, stabil terhadap suhu tinggi dan mengkilap (Nurminah, 2002).

Salah satu jenis kemasan plastik yang banyak digunakan saat ini adalah kemasan plastik polipropilen standing pouch karena menarik untuk dijadikan kemasan produk padat/kering maupun produk berbentuk cair. Kemasan jenis standing pouch dianggap sebagai salah satu jenis kemasan yang higienis karena tertutup rapat dan tidak ada celah untuk masuknya benda atau cairan. Selain itu plastik standing pouch juga memiliki kelebihan dari sisi desainnya yang cantik dan mudah untuk dikustomisasi (mudah disesuaikan dengan kebutuhan) serta ukurannya yang relatif lebih lebar dan posisinya yang bisa berdiri membuat 
desain tersebut mudah dilihat (Syahid; 2018).

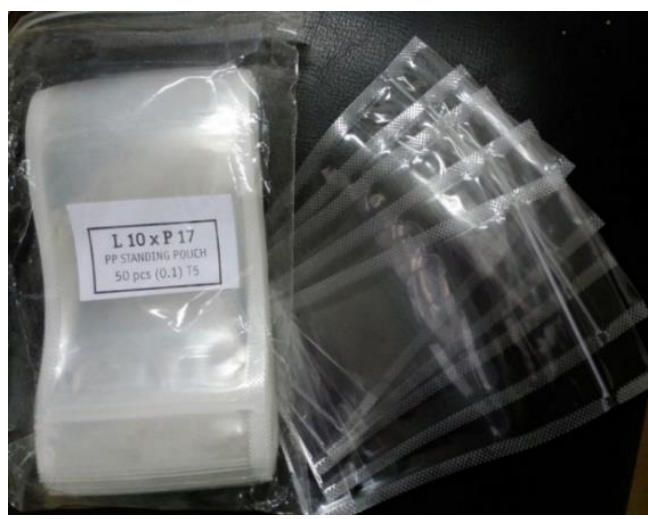

Gambar 1. Plastik Polipropilen standing pouch

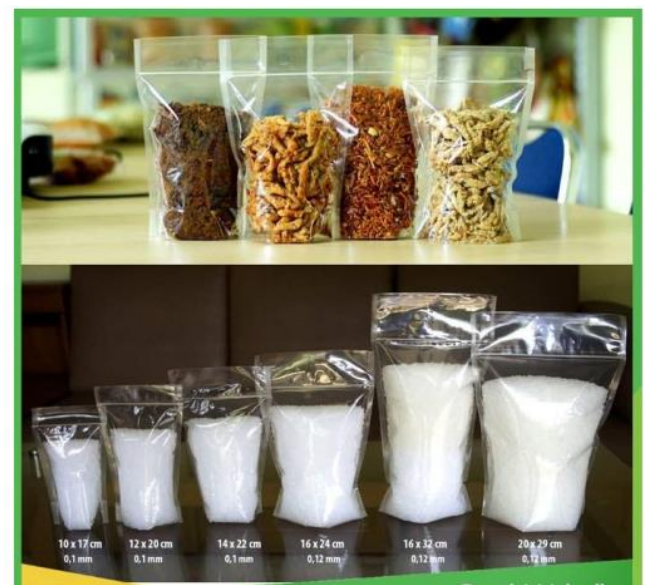

Gambar 2. Plastik standing pouch yang selama ini digunakan sebagai bahan pengemas makanan mempunyai berbagai ukuran, mulai dari ukuran yang kecil $(10 \times 17 \mathrm{~cm})$ hingga ukuran yang besar $(20 \times 29 \mathrm{~cm}$ ) (Sumber: Grosir Wahaji, 2018).

Sterilisasi adalah proses untuk membunuh semua mikroorganisme yang ada, dan jika ditumbuhkan pada medium tidak ada mikroorganisme yang tumbuh dan berkembang biak. Sterilisasi harus dapat membunuh mikroorganisme yang paling tahan panas yaitu spora bakteri (Fardiaz, 1992). Sterilisasi basah biasanya dilakukan dengan alat autoklaf uap dengan menggunakan uap air jenuh pada suhu $121{ }^{\circ} \mathrm{C}$ selama 15 menit. Penggunaan suhu $121^{\circ} \mathrm{C}$ itu disebabkan oleh tekanan 1 atm pada ketinggian permukaan laut. Autoklaf merupakan alat yang essensial dalam setiap laboratorium mikrobiologi, ruang sterilisasi di rumah sakit serta tempattempat lain yang memproduksi produk steril. Waktu yang diperlukan untuk sterilisasi tergantung pada sifat bahan yang akan disterilkan, tipe wadah dan volume bahan. Misal akan mensterilkan 1000 buah tabung reaksi yang masingmasing berisi $10 \mathrm{ml}$ medium cair membutuhkan waktu 10-15 menit pada suhu $121^{\circ} \mathrm{C}$, sedangkan jumlah medium yang sama bila ditempatkan dalam 10 wadah berukuran 1 liter akan membutuhkan waktu 20-30 menit pada suhu yang sama untuk menjamin tercapainya sterilisasi. (Pelczar dan Chan, 1986).

\section{METODE PENELITIAN}

Alat yang digunakan dalam percobaan ini antara lain: tip kuning, tip biru, tabung $1,5 \mathrm{ml}$, plastik standing pouch, kertas payung, gunting, isolasi, kotak tip pabrikan, autoklaf, inkubator $\mathrm{CO}_{2}$, oven. Bahan yang digunakan adalah medium RPMI 1640 steril dan akuades.

Metode yang digunakan adalah sterilisasi menggunakan autoklaf. Pada percobaan ini terdapat empat kelompok perlakuan. Masing-masing kelompok terdiri dari 3 atau lebih kemasan. Peralatan laboratorium yang dikemas antara lain: tip biru, tip kuning, tabung $1,5 \mathrm{ml}$, petridish. Kelompok pertama peralatan dikemas dalam plastik polipropilen standing pouch, kemudian plastik ditutup rapat dengan menekan klip penguncinya. Kelompok kedua peralatan dikemas dalam kertas payung yang berwarna coklat. Kelompok ketiga peralatan dikemas dalam plastik polipropilen tebal kemudian ditutup 
dengan selotip. Kelompok keempat peralatan dimasukkan dalam kotak tip pabrikan. Keempat kelompok tersebut dilakukan proses sterilisasi dengan autoklaf yang sudah berisi akuades dengan suhu $121^{\circ} \mathrm{C}$ dan tekanan $1 \mathrm{~atm}$ selama 15 menit. Setelah proses sterilisasi selesai, dilakukan pengamatan hasil dari perlakuan outoklaf terhadap kemasan dan peralatan yang ada didalam kemasan, kemudian peralatan tesebut dikeringkan dalam dalam oven dengan suhu $70^{\circ} \mathrm{C}$.

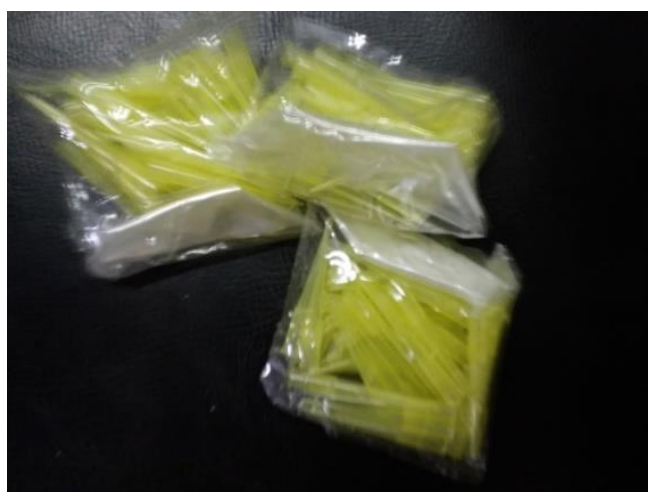

Gambar 3. Tip kuning yang dikemas dengan plastik tebal

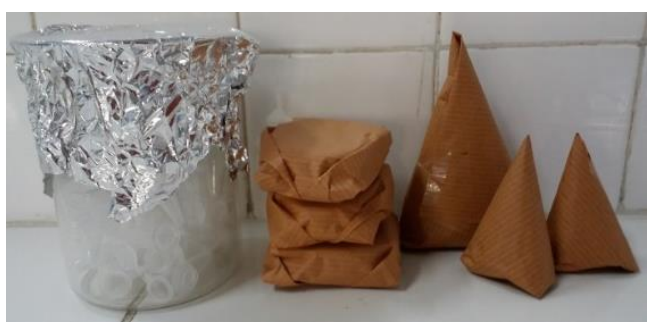

Gambar 4. Peralatan laboratorium yang sudah dikemas dengan kertas payung

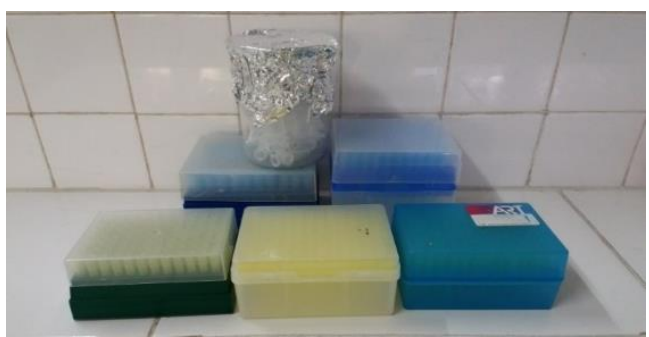

Gambar 5. Peralatan laboratorium yang dikemas dengan kotak tip pabrikan

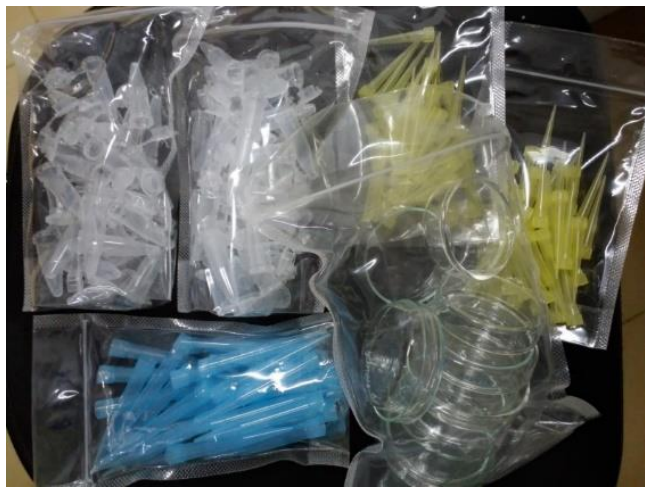

Gambar 6. Peralatan laboratorium yang sudah dikemas dengan plastik polipropilen standing pouch

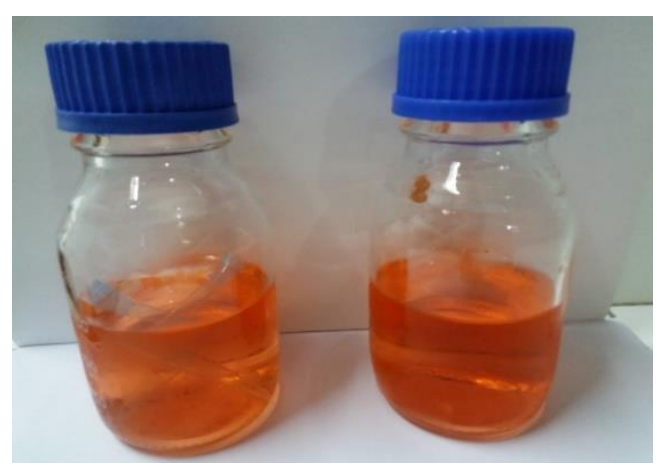

Gambar 7. Botol sebelah kiri berisi medium RPMI ditambah tip biru, botol sebelah kanan berisi medium RPMI saja sebagai kontrol

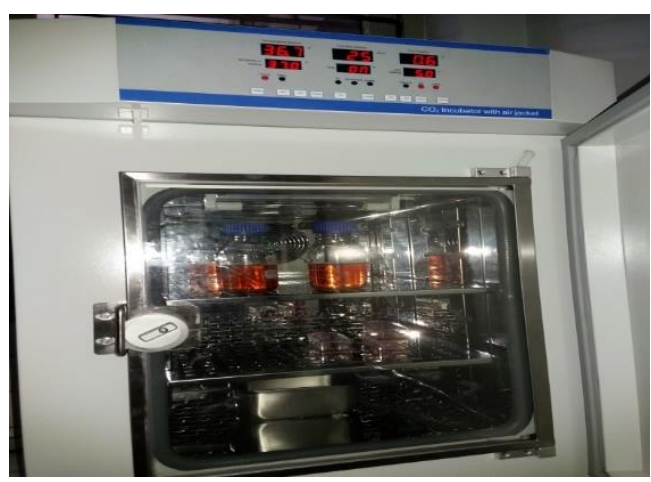

Gambar 8. Botol perlakuan dalam inkubator $\mathrm{CO}_{2}$

Percobaan selanjutnya adalah uji sterilitas peralatan laboratorium yang telah disterilkan menggunakan plastik PP standing pouch dengan cara menyiapkan dua buah botol steril yang telah berisi medium RPMI steril. Tip biru steril 
dimasukkan dalam botol pertama. Botol kedua sebagai kontrol. Kedua botol dimasukkan ke dalam inkubator $\mathrm{CO}_{2}$ dan dilakukan pengamatan selama tiga hari.

\section{HASIL DAN PEMBAHASAN}

Sterilisasi dalam percobaan ini menggunakan alat autoklaf dengan metode pemanasan dengan uap panas pada suhu $121^{\circ} \mathrm{C}$ dengan tekanan $1 \mathrm{~atm}$ selama 15 menit. Hal ini sesuai dengan Hadioetomo (1985), bahwa pemanasan basah biasanya dilakukan didalam autoklaf atau sterilisator uap yang mudah diangkat menggunakan uap air jenuh bertekanan pada suhu $121^{\circ} \mathrm{C}$ selama 15 menit. Metode sterilisasi ini sering dipakai karena lebih efisien, cepat, dan aman. Tujuan sterilisasi adalah menjaga kebersihan supaya peralatan terbebas dari mikroorgaisme berbahaya sehingga terhindar dari kontaminasi. Sreilisasi juga sebagai jaminan bahwa suatu produk sudah bersih, steril, dan aman digunakan oleh konsumen. Sterilisasi menggunakan cara pemanasan basah dapat membunuh mikroorganisme karena pemanasan basah dapat menyebabkan denaturasi protein, termasuk enzimenzim didalam sel (Fardiaz, 1992).

Percobaan sterilisasi peralatan kultur sel menggunakan bahan pengemas meliputi empat macam yaitu plastik propilen standing pouch, kertas payung, plastik polipropilen tebal dan kotak tip pabrikan. Sedangkan alat yang dikemas adalah tip kuning dan tip biru. Setelah dilakukan sterilisasi dengan menggunakan autoklaf, pengamatan dilakukan terhadap empat kemasan tersebut.

Hasil pengamatan pada kertas payung yaitu kondisi kemasan dalam keadaan basah dan mudah robek, beberapa ujung tip berwarna coklat, pada kemasan plastik polipropilen tebal terdapat selotip yang terlepas dari plastik karena pengaruh uap panas sehingga kemasan terbuka. Hasil pengamatan pada kemasan kotak tip pabrikan terlihat bahwa kotak mudah terbuka, oleh karena itu dibutuhkan plastik untuk melindungi kemasan kotak, juga terdapat beberapa kotak yang tidak tahan panas/meleleh, sedangkan pada kemasan plastik polipropilen standing pouch yaitu plastik tahan panas dan tidak meleleh, kemasan dalam keadaan tetap tertutup rapat karena terdapat klip pengunci.

Percobaan selanjutnya dilakukan pengecekan sterilitas peralatan hasil sterilisasi dengan kemasan plastik standing pouch menggunakan larutan medium. Gunawan (1988) mengatakan bahwa media kultur jaringan merupakan media yang sangat mendukung bagi pertumbuhan mikroba. Media yang digunakan pada percobaan ini adalah medium RPMI 1640 (Media Roswell Park Memorial Institute 1640) yang merupakan salah satu media yang banyak dipakai untuk menumbuhkan sel mamalia, salah satunya adalah sel limfosit. Media ini berwarna merah karena adanya phenol red sebagai indikator $\mathrm{pH}$ untuk mendeteksi terjadinya perubahan $\mathrm{pH}$ akibat metabolisme sel (Invitrogen, 2009).

Pengamatan dilakukan terhadap botol 1 dan 2 selama tiga hari. Botol 1 berisi medium RPMI yang ditambahkan tip biru yang telah disterilkan dengan kemasan plastik standing pouch. Botol kedua berisi medium saja sebagai kontrol. Pengamatan dilakukan secara visual. Pada hari pertama sampai hari ketiga medium dalam botol 1 dan 2 tetap jernih, hal ini menandakan bahwa tidak ada kontaminasi pada botol medium yang diberi tip biru, apabila terjadi kontaminasi maka medium RPMI akan berubah menjadi keruh. Hasil percobaan ini membuktikan bahwa tip biru steril dan peralatan steril lain yang dikemas 
dengan plastik polipropilen standing pouch dapat digunakan untuk bekerja pada penelitian yang menggunakan peralatan steril.

Keunggulan penggunaan plastik standing pouch adalah: murah, mudah didapatkan ditoko plastik, tebal, transparan, terdapat klip pengunci sehingga tidak memerlukan staples atau selotip, dan dapat dipakai berulang kali, juga bisa diletakkan pada posisi berdiri. Keunggulan tersebut sangat membantu peneliti, karena dapat mengurangi biaya penelitian skala kecil, misalnya penelitian mahasiswa S1.

\section{PENUTUP}

\section{Kesimpulan}

Plastik polipropilen standing pouch dapat digunakan sebagai bahan pengemas sterilisasi peralatan laboratorium.

\section{Saran}

Perlu mencari bahan pengemas lainnya untuk sterilisasi peralatan laboratorium yang lebih ramah lingkungan.

\section{DAFTAR PUSTAKA}

Fardiaz, S. 1992. Mikrobiologi Pangan I. Gramedia Pustaka Utama. Jakarta.

Gunawan, L.W. 1988. Teknik Kultur Jaringan, Laboratorium Kultur Jaringan, PAU Bioteknologi, IPB

Hadioetomo, R. S. 1985. Mikrobiologi Dasar dalam Praktek, Teknik dan Prosedur Dasar Laboratorium.Jakarta: Gramedia. https://elshinta.com/news/159775/2018/ 11/01/standing-pouch-pilihankemasan-yang-menarik-untukaneka-produk, diakses 23 April 2019

Invitrogen. 2009. RPMI media 1640 . diakses melalui http://www.invitrogen.com/site/us/ en/home/Products-and

Services/Applications/ CellCulture/Mammalian-

CellCulture/Classical_Media/RPM I.html pada 22 Agustus 2019.

Latief, 2000. Teknologi Kemasan Plastik Biodegradable. Hayati-IPB. Bogor.

Nurminah, M. 2002. Penelitian Sifat Berbagai Bahan Kemasan Plastik dan Kertas serta Pengaruhnya terhadap Bahan yang Dikemas, Fakultas Pertanian, Jurusan Teknologi Pangan, Universitas Sumatera Utara.

Pelczar, Michael J. dan Chan, E.C.S. 1986. 190-191, Dasar-Dasar Mikrobiologi, Universitas Indonesia, UI-Press, Jakarta

Syahid. 2018. Standing pouch, pilihan kemasan yang menarik untuk aneka produk 